\title{
Pengaruh Kompetensi dan Independensi Auditor Terhadap Kualitas Audit (Studi : Pada Kantor Akuntan Publik dan Badan Pemeriksa Keuangan di Sulawesi Utara)
}

\author{
Roland Mailuhu \\ Grace B. Mogi \\ Lintje Kalangi \\ Fakultas Ekonomi dan Bisnis Jurusan Akuntansi \\ Universitas Sam Ratulangi Manado \\ Email: rolandmailuhu@yahoo.com
}

\begin{abstract}
ABSTRAK
Profesi akuntan publik adalah fungsi atestasi/pengesahan (atesstation function). Ketika seorang auditor mengesahkan informasi mereka menerbitkan sebuah laporan dengan simpulan mengenai keyakinan suatu asersi tertulis dari manajemen. Untuk menghasilkan kualitas audit yang baik, auditor harus melakukan pekerjaannya sesuai dengan standar audit yang ditetapkan, yaitu sesuai dengan Standar Auditing dalam Standar Profesional Akuntan Publik (SPAP) atau Standar Pemeriksaan Keuangan Negara bagi auditor Badan Pemeriksa Keuangan (BPK). Kualitas Audit yang dihasilkan auditor juga dapat dipengaruhi oleh beberapa faktor, antara lain Kompetensi dan Independensi dari auditor. Kompetensi membantu auditor melaksanakan pekerjaan secara efektif dan efisien. Auditor juga harus independen dalam melaksanakan audit. Karena kompetensi yang baik tidak akan ada nilainya jika auditor tidak memiliki independensi yang tinggi dalam mengumpulkan dan mengevaluasi bukti. Penelitian ini bertujuan untuk menganalisis dan membuktikan bukti empiris pengaruh kompetensi dan independensi oleh Kantor Akuntan Publik (KAP) dan BPK RI Perwakilan Sulawesi Utara terhadap kualitas audit. Sedangkan untuk menjawab hipotesis penelitian menggunakan alat analisis regresi berganda. Berdasarkan hasil penelitian secara parsial dapat disimpulkan bahwa kompetensi berpengaruh positif tetapi tidak signifikan terhadap kualitas audit dan independensi berpengaruh positif dan signifikan terhadap kualitas audit. Secara simultan kompetensi dan independensi secara bersama-sama berpengaruh positif terhadap kualitas audit. Sehingga semakin tinggi kompetensi dan independensi seorang auditor, maka akan semakin baik kualitas audit yang dilakukan.
\end{abstract}

Kata Kunci : Kompetensi, Independensi dan Kualitas Audit

\begin{abstract}
Public accounting profession is a function of attestation / legalization ( atesstation function). When auditors certify the information they publish a report with conclusions regarding the conviction of a written assertion from management. To produce a good quality audit, the auditor should perform the work in accordance with the auditing standards defined, ie in accordance with Standards on Auditing in the Public Accountants Professional Standards ( SPAP ) or the Auditing Standards for the State Audit Agency (BPK ). The quality of the resulting audit the auditor may also be influenced by several factors, among others, competence and independence of the auditor. Competencies help auditors carry out the work effectively and efficiently. The auditor also should be independent in carrying out the audit. Because good competence would not be worth it if the auditor does not have the degree of independence in gathering and evaluating evidence. This study aims to analyze the influence of empirical evidence and prove the competence and independence by the Public Accountant (KAP) and North Sulawesi Representative BPK to audit quality. As for answering the research hypotheses using multiple regression analysis. Based on the partial results of the study it can be concluded that the competence of positive but not significant effect on audit quality and independence of positive and significant impact on audit quality. Competence and independence simultaneously jointly positive effect on audit quality. So the higher the competence and independence of the auditor, the better the quality of audits conducted.
\end{abstract}

Keywords : Competence, Independence and Quality Audit 


\section{PENDAHULUAN}

\section{Latar Belakang Penelitian}

Pada zaman sekarang, tujuan audit telah berubah. Penemuan kecurangan merupakan obyek audit yang insidental. Alasan pengembangan profesi akuntan publik adalah fungsi atestasi/pengesahan (atesstation function). Ketika seorang auditor mengesahkan informasi mereka menerbitkan sebuah laporan dengan simpulan mengenai keyakinan suatu asersi tertulis dari manajemen. Orang yang melakukan audit disebut auditor. Ada 3 macam auditor : (1) Auditor Independen, (2) Auditor Internal dan (3) Auditor Pemerintah. Auditing yang dilakukan oleh auditor independen yang merupakan suatu fungsi untuk menentukan apakah laporan keuangan yang disusun manajemen telah memenuhi pedoman atau kriteria yang telah disepakati bersama atau memenuhi ketentuan-ketentuan yang telah digariskan dalam Standar Akuntansi Keuangan (SAK).

Untuk menghasilkan kualitas audit yang baik, auditor harus melakukan pekerjaannya sesuai dengan standar audit yang ditetapkan, yaitu sesuai dengan Standar Auditing dalam Standar Profesional Akuntan Publik (SPAP) yang ditetapkan oleh Ikatan Akuntan Publik Indonesia (IAPI), Dalam melaksanakan audit, auditor harus mempunyai kompetensi di bidang akuntansi dan auditing serta memiliki independensi terhadap klien yang di audit. Kompetensi sangat dibutuhkan oleh auditor agar dapat melaksanakan tugas secara efektif dan efisien. Auditor harus memiliki keahlian dalam mengumpulkan dan menginterpretasikan bukti audit. Keahlian inilah yang membedakan auditor dan akuntan. Menentukan prosedur audit yang tepat, memutuskan jumlah dan unsur yang harus diuji, seta mengevaluasi hasilnya adalah tugas yang dilaksanakan oleh auditor. Dalam melaksanakan audit, auditor harus menggunakan seluruh keahliannya dalam bidang akuntansi dan auditing. Pencapaian keahlian dimulai dengan pendidikan formal, yang selanjutnya melalui pengalaman dan praktik audit. Dengan tingkat kompetensi yang cukup dan memadai, seorang auditor akan menghasilkan audit yang berkualitas. Sehingga kompetensi auditor akan mempengaruhi kualitas audit. Sebagai contoh, kasus yang terjadi pada PT. Kimia Farma dan kasus perusahaan energi terbesar di Amerika yaitu Enron. Yang menyebabkan dibubarkannya perusahaan akuntansi Arthur Andersen yang merupakan kantor Akuntan dari Enron.

Pada tanggal 2 november 2013 Badan Pemeriksa Keuangan (BPK) Republik Indonesia ingin mewujudkan opini Wajar Tanpa Pengecualian (Unqualified Opinion) Bebas Korupsi dalam lima tahun kedepan. Berita ini dimuat dalam web bpk.go.id. Untuk mengejar cita-cita ini tentunya ruang lingkup audit adalah secara keseluruhan bukan dengan teknik sampling, dan juga kompetensi serta independensi yang tinggi dari auditor sangat diperlukan untuk mencapai kualitas audit yang diinginkan.

Atas latar belakang di atas, maka peneliti mengangkat judul "Pengaruh Kompetensi dan Independensi Auditor Terhadap Kualitas Audit (Studi : Pada Kantor Akuntan Publik dan Badan Pemeriksa Keuangan di Sulawesi Utara)".

\section{Rumusan Masalah}

Bagaimanakah pengaruh kompetensi dan independensi auditor secara parsial dan simultan terhadap kualitas audit?

\section{Tujuan Penelitian}

Mengetahui pengaruh kompetensi dan independensi auditor secara parsial dan simultan terhadap kualitas audit pada Kantor Akuntan Publik (KAP) dan BPK di Sulawesi Utara.

\section{Manfaat Penelitian}

\section{A. Manfaat Teoritis}

Penelitian ini diharapkan dapat memberikan kontribusi pada pengembangan teori terutama yang berkaitan dengan auditing dan akuntansi terhadap pengujian empiris atas pengaruh kompetensi dan independensi auditor terhadap kualitas audit.

\section{B. Manfaat Praktis}

1. Bagi Penulis 
Penulis mendapat latihan dan penerapan disiplin ilmu yang diperoleh di bangku perkuliahan, serta dapat menambah pengalaman tentang menganalisis pengaruh kompetensi dan independensi auditor terhadap kualitas audit di KAP dan BPK di Sulawesi Utara.

2. Bagi auditor pada KAP dan BPK

Bagi auditor diharapkan dapat memberikan kontribusi dalam rangka meningkatkan profesionalisme profesi khususnya dalam meningkatkan kualitas audit.

\section{TINJAUAN PUSTAKA}

\section{Kajian Teori}

\section{A. Pengertian Auditing}

Menurut Arens dan Loebbecke (Auditing dan Jasa Assurance edisi 12, 2010 : 4) , auditing adalah pengumpulan dan evaluasi bukti tentang informasi untuk menentukan dan melaporkan derajat kesesuaian antara informasi itu dan kriteria yang telah ditetapkan.

\section{B. Standar Audit}

Standar audit yang telah ditetapkan dan disahkan oleh IAPI dan Peraturan Badan Pemeriksa Keuangan Republik Indonesia Nomor : 01 Tahun 2007 Tanggal : 7 Maret 2007 tentang Standar Pemeriksaan Keuangan Negara

\section{Pengertian Kualitas Audit}

De Angelo dalam Nugraha Eka Putra (2012:14) mendefinisikan kualitas audit sebagai kemungkinan (joint probability) dimana seorang auditor akan menemukan dan melaporkan pelanggaran yang ada dalam sistem akuntansi kliennya. Kemungkinan dimana auditor akan menemukan salah saji tergantung pada kualitas pemahaman auditor (kompetensi) sementara tindakan melaporkan salah saji tergantung pada independensi auditor.

\section{Faktor-Faktor yang Mempengaruhi Kualitas Audit}

a. Kompetensi

Definisi kompetensi dalam buku Manajemen Sumber Daya Manusia (2008;19-22), sebagai berikut:

Kamus Inggris Indonesia Echols dan kawan (1992) mengartikan kompetensi (competency) sebagai kemampuan atau kecakapan. Zemke (1982:30) menyatakan bahwa " a competency us a capability of an individual which relates to superior peformances in role or job. It maybe a knowlwdge, skill, intellectuall, strategy or a cluster of all three that may apply to one or may work unit. (artinya kompetensi merupakan kemampuan individu yang berhubungan dengan kinerja superior dalam peran dan pekerjaan. Kompetensi meliputi pengetahuan, keterampilan, intelektual, strategi, atau kombinasi dari ketiganya yang mungkin diaplikasikan pada seseotang atau mungkin unit kerja.

b. Independensi

Independensi menurut Arens dkk. (2010:111) berarti mengambil sudut pandang yang tidak bias. Auditor tidak hanya harus independen dalam fakta, tetapi juga harus independen dalam penampilan.

\section{Kajian Empiris}

Menurut Buku Panduan Penulisan Skripsi Dan Artikel - Tahun 2013 Ekonomi Manajemen Business Akuntansi $(2013 ; 20)$ kajian empiris atau penelitian terdahulu merupakan pencantuman penelitian-penelitian sebelumnya tentang variabel yang akan kita teliti. 
Tabel 1 Penelitian Terdahulu

\begin{tabular}{|c|c|c|c|c|}
\hline No & Peneliti & Topik Penelitian & Hasil Penelitian & $\begin{array}{l}\text { Perbedaan dan } \\
\text { Penelitian }\end{array}$ \\
\hline 1 & $\begin{array}{l}\text { Nugraha } \\
\text { Eka Putra, } \\
2012\end{array}$ & $\begin{array}{l}\text { Pengaruh } \\
\text { Kompetensi, } \\
\text { Tekanan Waktu, } \\
\text { Pengalaman Kerja, } \\
\text { Etika } \\
\text { Independensi } \\
\text { Auditor Terhadap } \\
\text { Kualitas Audit } \\
\text { (Studi : Pada Kantor } \\
\text { Akuntan Publik di } \\
\text { Daerah Istimewa } \\
\text { Yogyakarta). }\end{array}$ & $\begin{array}{l}\text { Hasil penelitian menunjukkan } \\
\text { bahwa: kompetensi auditor }\left(\mathrm{X}_{1}\right) \text {, } \\
\text { tekanan waktu auditor }\left(\mathrm{X}_{2}\right), \\
\text { pengalaman kerja auditor }\left(\mathrm{X}_{3}\right) \text {, } \\
\text { etika auditor }\left(\mathrm{X}_{4}\right) \text { dan } \\
\text { independensi auditor }\left(\mathrm{X}_{5}\right) \\
\text { mempunyai pengaruh signifikan } \\
\text { terhadap kualitas audit dan secara } \\
\text { simultan } \mathrm{X}_{1}, \mathrm{X}_{2}, \mathrm{X}_{3}, \mathrm{X}_{4} \text { dan } \mathrm{X}_{5} \\
\text { mempunyai pengaruh signifikan } \\
\text { terhadap kualitas audit. }\end{array}$ & $\begin{array}{l}\text { Persamaan penelitian ini adalah } \\
\text { sama-sama meneliti tentang } \\
\text { pengaruh kompetensi dan } \\
\text { independensi auditor terhadap } \\
\text { kualitas audit, sedangkan } \\
\text { perbedaannya adalah Penelitian } \\
\text { ini menambahkan variabel } \\
\text { tekanan waktu, pengalaman kerja } \\
\text { dan etika. }\end{array}$ \\
\hline 2 & $\begin{array}{l}\text { Harvita, } \\
\text { Yulian } \\
\text { Ayuningty } \\
\text { as, Sugeng } \\
\text { Pamudji, } \\
2011\end{array}$ & $\begin{array}{l}\text { Pengaruh } \\
\text { Pengalaman Kerja, } \\
\text { Independensi, } \\
\text { Objektivitas, } \\
\text { Integritas dan } \\
\text { Kompetensi Auditor } \\
\text { Terhadap Kualitas } \\
\text { Audit }\end{array}$ & $\begin{array}{l}\text { Menurut hasil penelitian, dapat } \\
\text { disimpulkan bahwa objektivitas, } \\
\text { integritas dan kompetensi secara } \\
\text { signifikan mempengaruhi kualitas } \\
\text { hasil audit, sementara pengalaman } \\
\text { dan kemandirian tidak secara } \\
\text { signifikan mempengaruhi kualitas } \\
\text { hasil audit. }\end{array}$ & $\begin{array}{l}\text { Persamaan penelitian ini adalah } \\
\text { sama-sama meneliti independensi } \\
\text { dan kompetensi, sedangkan } \\
\text { perbedaan penelitian ini: } \\
\text { Penelitian ini menambahkan } \\
\text { variabel pengalaman kerja, } \\
\text { objektivitas, intergritas. }\end{array}$ \\
\hline 3 & $\begin{array}{l}\text { Nungky } \\
\text { Nurmalita } \\
\text { Sari, } 2011\end{array}$ & $\begin{array}{l}\text { Pengaruh } \\
\text { Pengalaman Kerja, } \\
\text { Independensi, } \\
\text { Objektivitas, } \\
\text { Integritas dan Etika } \\
\text { Auditor Terhadap } \\
\text { Kualitas Audit }\end{array}$ & $\begin{array}{l}\text { Berdasarkan penelitian yang } \\
\text { terdahulu, terdapat pengaruh } \\
\text { positif antara variabel Kompetensi, } \\
\text { Pengalaman Kerja, Etika dan } \\
\text { Independensi. }\end{array}$ & $\begin{array}{l}\text { Persamaan penelitian ini adalah } \\
\text { sama-sama meneliti variabel } \\
\text { dependen yaitu kualitas audit } \\
\text { Sedangkan perbedaannya adalah } \\
\text { Peneliti meneliti variabel } \\
\text { Kompetensi dan d dan } \\
\text { independensi sebagai variabel } \\
\text { independen. }\end{array}$ \\
\hline 4 & $\begin{array}{l}\text { ST Nur } \\
\text { Irawati, } \\
2011\end{array}$ & $\begin{array}{l}\text { Pengaruh } \\
\text { Kompetensi dan } \\
\text { Independensi } \\
\text { terhadap Kualitas } \\
\text { Audit pada kantor } \\
\text { Akuntan Publik di } \\
\text { Makassar }\end{array}$ & $\begin{array}{l}\text { Berdasarkan hasil penelitian dapat } \\
\text { disimpulkan bahwa secara parsial } \\
\text { hanya independensi yang } \\
\text { berpengaruh terhadap kualitas } \\
\text { audit sedangkan secara simultan } \\
\text { kompetensi dan independensi } \\
\text { auditor berpengaruh terhadap } \\
\text { kualitas audit. }\end{array}$ & $\begin{array}{l}\text { Persamaan penelitian sekarang } \\
\text { dengan terdahulu yaitu sama- } \\
\text { sama meneliti tentang Pengaruh } \\
\text { Kompetensi dan Independensi } \\
\text { terhadap Kualitas Audit. }\end{array}$ \\
\hline 5 & $\begin{array}{l}\text { Siti Nur } \\
\text { Mawar } \\
\text { Indah, } \\
2010\end{array}$ & $\begin{array}{l}\text { Pengaruh } \\
\text { Kompetensi dan } \\
\text { Independensi } \\
\text { Auditor Terhadap } \\
\text { Kualitas Audit }\end{array}$ & $\begin{array}{l}\text { Berdasarkan hasil penelitian dapat } \\
\text { disimpulkan bahwa pengalaman } \\
\text { dalam melaksanakan audit, } \\
\text { pengetahuan seorang auditor serta } \\
\text { telaah dari rekan auditor (peer } \\
\text { review) berpengaruh positif } \\
\text { terhadap kualitas audit. }\end{array}$ & $\begin{array}{l}\text { Persamaan penelitian ini dengan } \\
\text { relevan adalah sama-sama } \\
\text { meneliti tentang pengaruh } \\
\text { Kompetensi dan Independensi } \\
\text { terhadap kualitas Audit. }\end{array}$ \\
\hline
\end{tabular}

Sumber : Data Primer, 2014 


\section{Kerangka Pemikiran}

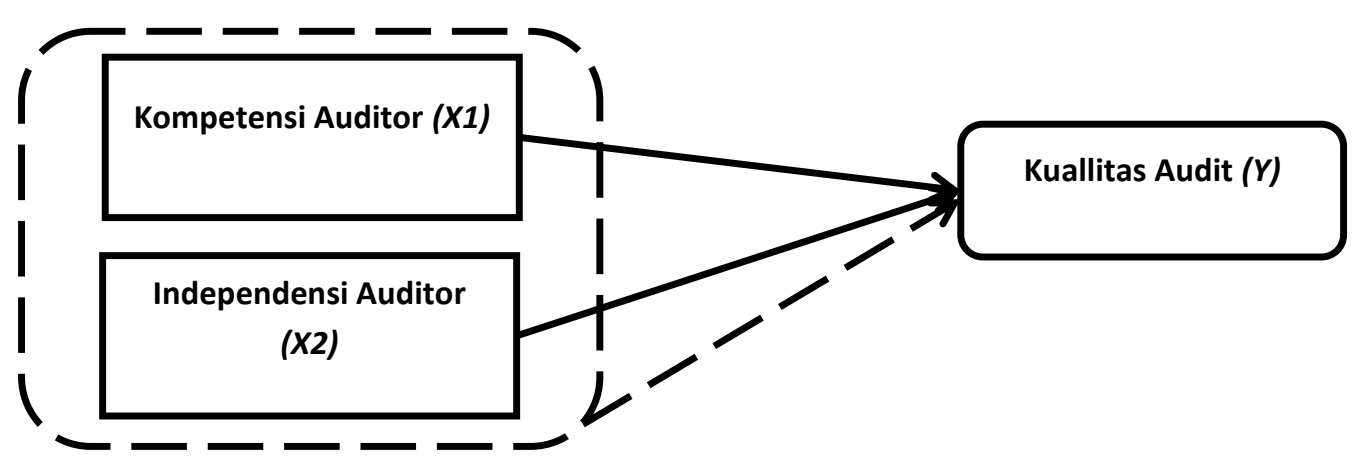

Gambar 1 Kerangka Pemikiran

Keterangan Gambar :

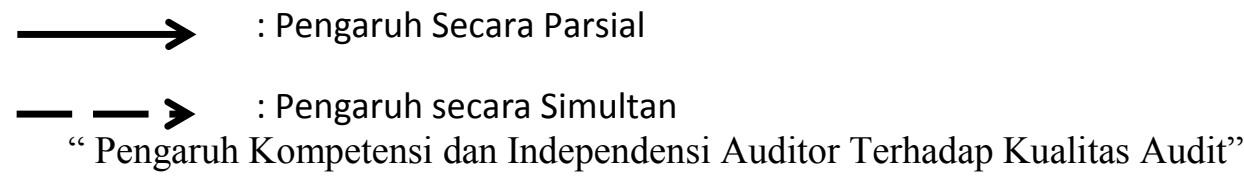

\section{Hipotesis Penelitian}

Berdasarkan deskripsi teori dan kerangka berpikir, maka dapat dirumuskan hipotesis penelitian sebagai berikut:

1. Pengaruh Kompetensi Auditor Terhadap Kualitas Audit

$\mathrm{H}_{1}$ : Kompetensi Auditor berpengaruh positif terhadap Kualitas Audit

2. Pengaruh Independensi Auditor Terhadap Kualitas Audit

$\mathrm{H}_{2}$ : Independensi Auditor berpengaruh positif terhadap Kualitas Audit

3. Pengaruh Kompetensi dan Indpendensi Auditor Terhadap Kualitas Audit

$\mathrm{H}_{3}$ : Kompetensi dan Independesi Auditor secara simultan berpengaruh positif terhadap Kualitas Audit

\section{METODE PENELITIAN}

\section{Jenis Penelitian}

Penelitian ini merupakan penelitian deskriptif kuantitatif. Bambang Prasetyo dan Lina Miftamul Jannah (2010:42) penelitian ini dilakukan untuk memberikan gambaran yang lebih detail mengenai suatu gejala atau fenomena.

\section{Tempat dan Waktu Penelitian}

A. Tempat Penelitian

Penelitian ini dilakukan pada 3 (Tiga) Kantor Akuntan Publik (KAP) dan Badan Pemeriksa Keuangan Sulawesi Utara

B. Waktu Penelitian

Penelitian akan dilakukan pada bulan November 2013 sampai dengan Januari 2014.

\section{Prosedur Penelitian}

1. Perencanaan Penelitian, meliputi: penentuan tema/masalah, studi pendahuluan, penyusunan proposal, pengembangan instrument, proses perizinan.

2. Pengumpulan data

3. Pengolahan data

4. Penyajian data kedalam bentuk tabel

5. Analisa dan intepretasi data 


\section{Penyususan laporan}

\section{Populasi dan Sampel}

Riduan dan Lestari (1997:3) dalam Supardi (2013:25) populasi adalah keseluruhan dari karakteristik atau unit hasil pengukuran yang menjadi obyek penelitian.

\section{Metode Pengumpulan Data}

HM. Sonny Sumarsono (2004:70-73) teknik pengumpulan data terbagi atas : pengamatan langsung, wawancara, pengisian daftar pertanyaan, studi pustaka.

\section{Metode Analisis}

Metode analisis data yang digunakan pada penelitian ini adalah analisis regresi linier berganda (multiple linear regression analysis). Analisis regresi linier berganda adalah hubungan secara linear antara dua atau lebih variabel independen $\left(\mathrm{X}_{1}, \mathrm{X}_{2}, \ldots \mathrm{X}_{\mathrm{n}}\right)$ dengan variabel dependen $(\mathrm{Y})$.

Persamaan regresi linier berganda adalah sebagai berikut :

$$
Y=\alpha+\beta_{1} X_{1}+\beta_{2} X_{2}+e
$$

Keterangan :

Y : Kualitas Audit.

$\mathrm{X} 1 \quad$ : Kompetensi

X2 : Independensi

$\alpha \quad$ : Konstanta.

$\beta \quad$ : Koefisien Regresi.

e : Error.

\section{A. Metode Analisis Data}

Statistik deskriptif merupakan proses transformasi data penelitian dalam bentuk tabulasi data responden yang diperoleh dari kuesioner serta penjelasannya sehingga mudah dipahami dan diinterpretasikan.

\section{B. Uji Kualitas Data}

Pengujian validitas dan reabilitas kuesioner dalam penelitian ini menggunakan program SPSS (Statistical Product and Service Solution).

1) Uji Validitas

Validitas adalah ukuran yang menunjukkan sejauh mana instrument pengukur mampu mengukur apa yang ingin diukur. Data dinyatakan valid jika nilai r-hitung yang merupakan nilai dari Corrected Item-Total Correlation $>$ dari r-tabel pada signifikansi $0.05(5 \%)$. Atau jika melakukan penilaian langsung terhadap koefisien korelasi, bisa digunakan batas nilai minimal korelasi 0,30 .

2) Uji Realibilitas

Realibilitas adalah ukuran yang menunjukkan konsistensi dari alat ukur dalam mengukur gejala yang sama di lain kesempatan. Realibilitas suatu variabel yang dibentuk dari daftar pertanyaan dikatakan baik jika memiliki nilai Cronbach's Alpha > dari 0,60.

\section{Uji Asumsi Klasik}

Asumsi klasik tersebut, yaitu : uji normalitas, uji multikolineritas dan uji heteroskedastisitas.

\section{Uji Hipotesis}

Uji hipotesis dalam penelitian ini akan diuji dengan menggunakan analisis regresi linear. Untuk menguji hipotesis mengenai kompetensi dan indepensi auditor digunakan pengujian hipotesis secara simultan dengan uji $\mathrm{F}$ dan secara parsial dengan uji t.

\section{Definisi dan Pengukuran Variabel}

\section{A. Variabel Penelitian} negatif.

Variabel independen adalah variabel yang mempengaruhi variabel dependen, baik secara positif ataupun

\section{B. Definisi Operasional dan Pengukuran Variabel}

a. Variabel bebas : 
$\mathrm{X}_{1}=$ Kompetensi

$\mathrm{X}_{2}=$ Independensi

b. Variabel Terikat :

$\mathrm{Y}=$ Kualitas audit

Pengukuran variabel di dalam penelitian ini adalah dengan memberikan skor atau nilai dalam penelitian ini digolongkan dalam lima tingkatan, yaitu: Jawaban SS (Sangat Setuju) diberi nilai 5, Jawaban S (Setuju) diberi nilai 4, Jawaban N (Netral) diberi nilai 3, Jawaban TS (Tidak Setuju) diberi nilai 2, Jawaban STS (Sangat Tidak Setuju) diberi nilai 1.

\section{Hasil Penelitian}

\section{HASIL PENELITIAN DAN PEMBAHASAN}

\section{A. Gambaran Umum Responden}

\begin{tabular}{ccccc}
\hline No & Nama KAP & Alamat KAP & Jumlah Responden & \% \\
\hline 1 & Kindangen, Drs & Jl. Sudirman no. 130 & 5 orang & $16.7 \%$ \\
\hline 2 & Ariesman Auly, Drs & Jl. Martadinata VII no. 18 & 9 orang & $30 \%$ \\
\hline 3 & J. Sondakh \& G. Nangoi & Jl. S. Parman no. 53 & 5 orang & $16.7 \%$ \\
\hline 4 & $\begin{array}{c}\text { BPK Perwakilan Sulawesi } \\
\text { Utara }\end{array}$ & Jl. 17 Agustus No. 04 & 11 orang & $36.6 \%$ \\
\hline \multicolumn{2}{c}{ Total Responden } & 30 orang & $100 \%$ \\
\hline
\end{tabular}

Sumber : Data diolah, 2014

Tabel 2 Jumlah Responden

Tabel 3 Komposisi Responden Berdasarkan Jenis Kelamin

\begin{tabular}{ccc}
\hline Jenis Kelamin & Jumlah & Presentase \\
\hline Pria & 18 orang & $60 \%$ \\
\hline Wanita & 11 orang & $36.7 \%$ \\
\hline Tidak Mengisi & 1 orang & $3.3 \%$ \\
\hline Total & 30 orang & $100 \%$ \\
\hline
\end{tabular}

Sumber : Data diolah, 2014

Tabel 4 Komposisi Responden Berdasarkan Umur

\begin{tabular}{ccc}
\hline Umur & Jumlah & Presentase \\
\hline$\leq 25$ Tahun & 5 orang & $16.7 \%$ \\
\hline $26-30$ Tahun & 14 orang & $46.7 \%$ \\
\hline $36-55$ Tahun & 8 orang & $26.6 \%$ \\
\hline$>55$ Tahun & 3 orang & $10 \%$ \\
\hline Total & 30 orang & $100 \%$ \\
\hline
\end{tabular}

Sumber : Data Hasil Olahan, 2014

Tabel 5 Komposisi Responden Berdasarkan Tingkat Pendidikan Terakhir

\begin{tabular}{ccc}
\hline Tingkat Pendidikan & Jumlah & Presentase \\
\hline S3 & 1 orang & $3.3 \%$ \\
\hline S2 & 2 orang & $6.7 \%$ \\
\hline S1 dengan Profesi Akuntan & 11 orang & $36.7 \%$ \\
\hline S1 & 11 orang & $36.7 \%$ \\
\hline D3 & 5 orang & $16.6 \%$ \\
\hline Total & 30 orang & $100 \%$ \\
\hline
\end{tabular}

Sumber : Data diolah, 2014

Tabel 6 Komposisi Responden Berdasarkan Jabatan 


\begin{tabular}{ccc}
\hline Jabatan & Jumlah & Presentase \\
\hline Partner & 1 orang & $3.3 \%$ \\
\hline Manager & 2 orang & $6.7 \%$ \\
\hline Senior Auditor & 9 orang & $30 \%$ \\
\hline Junior Auditor & 16 orang & $53.3 \%$ \\
\hline Tidak Mengisi & 2 orang & $6.7 \%$ \\
\hline Total & 30 orang & $100 \%$ \\
\hline
\end{tabular}

Sumber : Data diolah, 2014

\section{B. Uji Validitas dan Reliabilitas}

Tabel 7 Hasil Uji Validitas dan Reliabilitas

\begin{tabular}{|c|c|c|c|}
\hline & Kompetensi $\left(\mathrm{X}_{1}\right)$ & Independensi $\left(\mathrm{X}_{2}\right)$ & Kualitas Audit (Y) \\
\hline $\begin{array}{l}\text { Corrected Item-Total Correlation } \\
\text { P1 }\end{array}$ & 0.575 & 0.430 & .437 \\
\hline $\begin{array}{l}\text { Corrected Item-Total Correlation } \\
\text { P2 }\end{array}$ & 0.688 & 0.552 & .415 \\
\hline $\begin{array}{l}\text { Corrected Item-Total Correlation } \\
\text { P3 }\end{array}$ & 0.829 & 0.646 & .409 \\
\hline $\begin{array}{l}\text { Corrected Item-Total Correlation } \\
\text { P4 }\end{array}$ & 0.648 & 0.822 & .609 \\
\hline $\begin{array}{l}\text { Corrected Item-Total Correlation } \\
\text { P5 }\end{array}$ & 0.529 & 0.412 & .559 \\
\hline $\begin{array}{l}\text { Corrected Item-Total Correlation } \\
\text { P6 }\end{array}$ & 0.419 & 0.833 & .660 \\
\hline $\begin{array}{l}\text { Corrected Item-Total Correlation } \\
\text { P7 }\end{array}$ & 0.685 & 0.712 & .747 \\
\hline $\begin{array}{l}\text { Corrected Item-Total Correlation } \\
\text { P8 }\end{array}$ & 0.374 & 0.695 & .587 \\
\hline $\begin{array}{l}\text { Corrected Item-Total Correlation } \\
\text { P9 }\end{array}$ & 0.380 & 0.822 & .429 \\
\hline $\begin{array}{l}\text { Corrected Item-Total Correlation } \\
\text { P10 }\end{array}$ & 0.380 & 0.610 & .492 \\
\hline $\begin{array}{l}\text { Corrected Item-Total Correlation } \\
\text { P11 }\end{array}$ & 0.354 & 0.847 & .529 \\
\hline $\begin{array}{l}\text { Corrected Item-Total Correlation } \\
\text { P12 }\end{array}$ & 0.707 & 0.777 & .653 \\
\hline Cronbach's Alpha & 0.749 & 0.768 & 0.747 \\
\hline
\end{tabular}

Sumber : Data diolah SPSS, 2014

Berdasarkan hasil uji validitas dan reliabilitas untuk pertanyaan 1-12 untuk variabel $\mathrm{X}_{1}, \mathrm{X}_{2}$ dan $\mathrm{Y}$, mempunyai nilai korelasi di atas 0,30 dan cronbach alpha $\geq 0,6$. Semua dinyatakan reliabel dan valid.

C. Uji Asumsi Klasik

1) Uji Normalitas

Gambar 2 Hasil Uji Normalitas Menggunakan Grafik P-Plot 


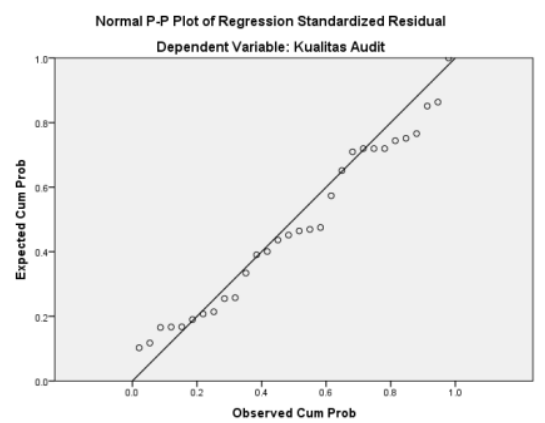

Sumber : Data Hasil Olahan SPSS, 2014

Gambar 4.1 menunjukkan adanya persebaran data (titik) pada sumbu diagonal yang mendekati garis diagonal. Melihat hal tersebut maka dapat disimpulkan penelitian ini memenuhi uji normalitas.

2) Uji Heteroskedastisitas

Pada uji heteroskedastisitas titik-titik tidak membentuk suatu pola yang jelas, serta titik-titik menyebar di atas dan di bawah angka 0 (nol) pada sumbu Y, hal ini membuktikan tidak terjadi heteroskedastisitas.

\section{Gambar 3 Hasil Uji Heteroskedastisitas}

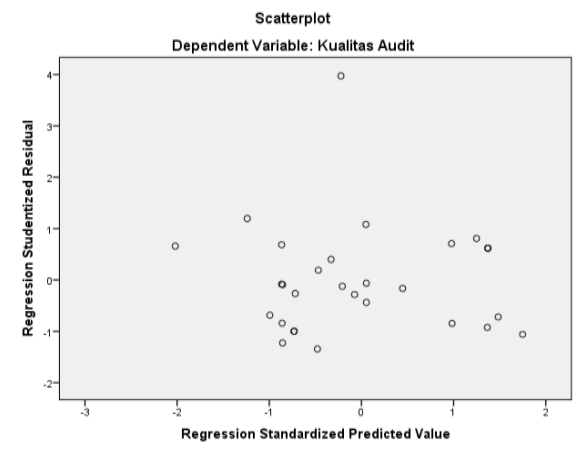

Sumber : Data diolah SPSS, 2014

3) Uji Multikoleniaritas

Tabel 9 Uji Multikoleniaritas

\begin{tabular}{lllll}
\hline \multicolumn{2}{c}{ Model } & \multicolumn{3}{c}{ Collinearity Statistics } \\
\cline { 3 - 4 } \multicolumn{1}{c}{} & \multicolumn{2}{c}{ Tolerance } \\
\hline & (Constant) & & VIF \\
\cline { 2 - 4 } & Kompetensi & .537 & 1.864 \\
\cline { 2 - 4 } & Independensi & .537 & 1.864 \\
\hline
\end{tabular}

Sumber : Data diolah SPSS, 2014

Berdasarkan hasil coefficients yang terdapat pada tabel 4.7 dapat dilihat pada output coefficients model, dikatakan tidak terjadi gejala multikolinearitas jika $V I F<5$. Nilai $V I F$ untuk variabel kompetensi $\left(\mathrm{X}_{1}\right)$ adalah sebesar 1,864 < 5 dan nilai tolerance 0,537 > 0,10 dan nilai VIF independensi $\left(\mathrm{X}_{2}\right)$ adalah $1,864<5$ dan nilai tolerance $0,537>0,10$. Maka penelitian ini tidak terjadi gejala multikolinearitas dalam model penelitian ini.

D. Uji Hipotesis

Pengujian hipotesis dilakukan dengan menggunakan analisis regresi linear berganda dengan tingkat signifikan $\alpha=0.05$ yang terdiri dari : pengujian korelasi atau koefisien determinasi, uji $\mathrm{f}$ dan uji t.

1. Hasil Uji Korelasi dan Determinasi $\left(\mathrm{R}^{2}\right)$

a. Koefisien Korelasi (r) 
Tabel 10 Koefisien Korelasi

\section{Correlations}

\begin{tabular}{llrrr}
\hline & & Kualitas Audit & Kompetensi & \multicolumn{1}{c}{ independensi } \\
\hline \multirow{2}{*}{ Pearson Correlation } & Kualitas Audit & 1.000 & .680 & .734 \\
\cline { 2 - 5 } & Kompetensi & .680 & 1.000 & .681 \\
\cline { 2 - 5 } & Independensi & .734 & .681 & 1.000 \\
\hline \multirow{2}{*}{ Sig. (1-tailed) } & Kualitas Audit & .000 & .000 & .000 \\
\cline { 2 - 5 } & Kompetensi & .000 & .000 & .000 \\
\cline { 2 - 5 } & Independensi & 30 & 30 & 30 \\
\hline $\mathrm{N}$ & Kualitas Audit & 30 & 30 & 30 \\
\cline { 2 - 5 } & Kompetensi & 30 & 30 & 30 \\
\cline { 2 - 5 } & Independensi & & &. \\
\hline
\end{tabular}

Sumber : Data diolah SPSS, 2014

Hasil olahan data menunjukkan bahwa variabel kompetensi $\left(\mathrm{X}_{1}\right)$ mempunyai korelasi yang bersifat kuat, positif dan signifikan dengan kualitas audit (Y) hal ini ditunjukkan dengan nilai koefisien korelasi sebesar 0,680 > 0,5 .

Untuk variabel independensi $\left(\mathrm{X}_{2}\right)$ mempunyai korelasi yang bersifat kuat, positif dan signifikan dengan kualitas audit (Y) dengan nilai koefisien korelasi sebesar 0,743 > 0,5.

b. Koefisien Determinasi $\left(\mathrm{R}^{2}\right)$

Tabel 11 Koefisien Determinasi Model Summary $^{\mathbf{b}}$

\begin{tabular}{llrrr}
\hline Model & $\mathrm{R}$ & $\mathrm{R}$ Square & Adjusted R Square & Std. Error of the Estimate \\
\hline 1 & $.774^{\mathrm{a}}$ & .599 & .569 & 2.730 \\
\hline
\end{tabular}

a. Predictors: (Constant), independensi, kompetensi

b. Dependent Variable: kualitas audit

Sumber : Data diolah SPSS, 2014

Pada tabel 4.9 diatas dapat diketahui besarnya koefisien determinasi $\left(\mathrm{R}^{2}\right)$ terlihat dari nilai adjusted $R$ square karena penelitian ini memiliki lebih dari satu variabel bebas. Koefisien adjusted $\mathrm{R}$ square adalah sebesar 0,569 atau 56,9\%. Maka data dapat disimpulkan bahwa variabel kualitas audit (Y) yang dapat dijelaskan oleh variabel kompetensi $\left(\mathrm{X}_{1}\right)$ dan independensi $\left(\mathrm{X}_{2}\right)$ adalah sebesar 56,9\%. Sedangkan sisanya 43,1\% dijelaskan oleh variabel lainnya yang tidak dimasukkan dalam model regresi. Variabel lainnya seperti pengalaman kerja, tekanan anggaran waktu, etika dan lain-lain.

2. Hasil Uji t (Parsial)

Tabel 12 Hasil Uji t untuk Hipotesis Coefficients $^{\mathrm{a}}$

\begin{tabular}{|c|c|c|c|c|c|c|}
\hline \multirow{2}{*}{\multicolumn{2}{|c|}{ Model }} & \multirow{2}{*}{$\begin{array}{c}\text { Standardized Coefficients } \\
\text { Beta }\end{array}$} & \multirow[t]{2}{*}{$\mathrm{T}$} & \multirow[t]{2}{*}{ Sig. } & \multicolumn{2}{|c|}{$95.0 \%$ Confidence Interval for B } \\
\hline & & & & & Lower Bound & Upper Bound \\
\hline \multirow[t]{3}{*}{1} & (Constant) & & 1.160 & .256 & -6.794 & 24.463 \\
\hline & Kompetensi & .337 & 2.027 & .053 & -.005 & .828 \\
\hline & independensi & .504 & 3.029 & .005 & .138 & .717 \\
\hline
\end{tabular}

a. Dependent Variable: Kualitas Audit

T Tabel : 2.048

Sumber : Data diolah SPSS, 2014 
Hasil pengujian hipotesis dengan uji t pada signifikansi $\alpha=5 \%$ pada derajat kebebasan $(\mathrm{N}-2)=30-2=28$, dapat diketahui nilai t tabel sebesar 2,048 adalah sebagai berikut:

a. Variabel kompetensi $\left(\mathrm{X}_{1}\right)$ memiliki t hitung 2,027 unit lebih kecil dari t tabel 2,048 unit ( $\mathrm{t}$ hitung 2,027 < t tabel 2,048 ) dan signifikansi 0,053 yang lebih besar dari 0,05. Dengan demikian, pengujian menunjukkan variabel kompetensi berpengaruh positif terhadap kualitas audit tetapi tidak terlalu signifikan.

b. Variabel independensi $\left(\mathrm{X}_{2}\right)$ memiliki t hitung 3,029 unit lebih besar dari t tabel 2,048 ( $\mathrm{t}$ hitung 3,029 $>\mathrm{t}$ tabel 2,048 ) dan signifikansi 0,005 yang lebih kecil dari 0,05. Dengan demikian, pengujian menunjukkan variabel independensi berpengaruh signifikan terhadap kualitas audit.

3. Hasil Uji F (Simultan)

Pengujian signifikan simultan (uji F) dilakukan untuk menunjukkan apakah semua variabel independen yang digunakan dalam model regresi mempunyai pengaruh yang signifikan secara bersama-sama terhadap variabel dependen. Hasilnya dapat dilihat pada tabel berikut:

Tabel 13 Hasil Uji F

\begin{tabular}{lllrrrr}
\hline & \multicolumn{6}{c}{ ANOVA $^{\mathbf{b}}$} \\
\hline \multirow{2}{*}{ Model } & \multicolumn{1}{c}{$\begin{array}{c}\text { Sum of } \\
\text { Squares }\end{array}$} & Df & Mean Square & F & Sig. \\
\hline \multirow{2}{*}{1} & Regression & 300.719 & 2 & 150.360 & 20.169 & $.000^{\text {a }}$ \\
\cline { 2 - 7 } & Residual & 201.281 & 27 & 7.455 & & \\
\cline { 2 - 7 } & Total & 502.000 & 29 & & & \\
\hline
\end{tabular}

a. Predictors: (Constant), independensi, kompetensi

b. Dependent Variable: kualitas audit

Sumber : Data diolah SPSS, 2014

Berdasarkan hasil pengolahan data pada tabel 4.11 menunjukkan bahwa dari uji $\mathrm{F}$ test nilai $\mathrm{F}$ hitung sebesar 20.169 unit. Angka ini lebih besar dari F tabel 3.35 dengan nilai signifikan sebesar 0.000 atau lebih kecil dari nilai probabilitas (p-value) $0,05(0,000<0,05)$. Dengan demikian maka dapat disimpulkan bahwa Ho ditolak yang berarti bahwa pengaruh kompetensi dan independensi secara bersama-sama (simultan) mempunyai pengaruh signifikan terhadap kualitas audit.

4. Regresi Linear Berganda

Tabel 14 Tabel Regresi Berganda Coefficients $^{\mathrm{a}}$

\begin{tabular}{lllrr}
\hline \multicolumn{2}{l}{ Model } & \multicolumn{3}{c}{ Unstandardized Coefficients } \\
\cline { 3 - 5 } & & B & \multicolumn{2}{c}{ Std. Error } \\
\hline \multirow{2}{*}{1} & (Constant) & 8.834 & 7.617 \\
\cline { 2 - 5 } & Kompetensi & .411 & .203 \\
\cline { 2 - 5 } & independensi & .428 & .141 \\
\hline
\end{tabular}

Sumber : Data diolah SPSS, 2014

Berdasarkan hasil analisis regresi berganda diatas, maka dapat dihasilkan model regresi sebagai berikut: Persamaan (4.1) : Y = 8,834 +0,411 $\mathrm{X}_{1}+0,428 \mathrm{X}_{2}$

Dari hasil persamaan (4.1) dapat disimpulkan, jika variabel kompetensi dan independensi konstan maka kualitas audit auditor adalah bertambah. Jika seorang auditor memiliki kompetensi dalam bidang audit maka akan meningkatkan kualitas audit seorang auditor. Dan jika seorang auditor bersikap independen dalam setiap proses audit maka akan meningkatkan kualitas audit.

E. Pembahasan

A. Pengaruh kompetensi secara parsial terhadap kualitas audit 
Dari penelitian ini, diperoleh hasil bahwa kompetensi secara parsial mempunyai pengaruh positif terhadap kualitas audit tetapi tidak terlalu signifikan. Penelitian ini didukung oleh penelitian Nungky, dkk (2011), ST Nur, dkk (2011) dan Siti Nur (2010) yang menyatakan bahwa kompetensi berpengaruh positif terhadap kualitas audit tetapi tidak signifikan.

B. Pengaruh independensi secara parsial terhadap kualitas audit

Independensi secara parsial mempunyai pengaruh yang signifikan terhadap kualitas audit. Sikap independensi auditor yang kuat akan meningkatkan kualitas audit yang dihasilkan oleh auditor tersebut. Hasil penelitian ini didukung oleh penelitian yang dilakukan oleh Nugraha Eka Putra (2012), Harvita (2011), Nungky, dkk (2011), ST Nur (2011) dan Siti Nur (2010) dimana independensi mempunyai pengaruh positif dan signifikan terhadap kualitas audit. Dengan independensi yang tinggi, auditor dapat melaksanakan auditnya dengan bebas dan tidak terpengaruh oleh klien atau apapun yang dapat mengubah opini audit yang akan diberikan kepada klien

C. Pengaruh kompetensi dan independensi secara simultan terhadap kualitas audit

Hasil penelitian ini secara simultan diketahui bahwa kualitas audit pada auditor di KAP dan BPK Perwakilan RI di Sulawesi Utara dapat ditentukan oleh faktor kompetensi dan independensi dalam koefisien determinasi $\mathrm{R}^{2}$ adalah 56,9 \% dan selebihnya $43.1 \%$ ditentukan oleh faktor lain diluar model penelitian ini. Penelitian ini didukung oleh penelitian Nugraha Eka Putra (2012), Havita (2011), Nungky, dkk (2011), ST Nur , dkk (2011) dan Siti Nur (2010) dimana secara simultan kompetensi dan independensi berpengaruh signifikan terhadap kualitas audit. Dengan kompetensi yang memadai dan didukung dengan sikap independen yang tinggi dari auditor akan menghasilkan kualitas audit yang baik.

\section{Kesimpulan}

\section{PENUTUP}

a. Kompetensi seorang auditor berpengaruh positif terhadap kualitas audit tetapi tidak signifikan, sehingga semakin tinggi tingkat kompetensi seorang auditor maka akan semakin baik kualitas audit yang dihasilkan.

b. Independensi seorang auditor berpengaruh positif dan signifikan terhadap kualitas audit, sehingga semakin tinggi independensi yang dimiliki seorang auditor maka semakin baik kualitas audit yang dihasilkan. Namun jika tidak memiliki independensi terutama jika mendapat tekanan-tekanan dari pihak klien maka kualitas audit yang dihasilkannya juga tidak maksimal.

c. Kompetensi dan independensi secara bersama-sama berpengaruh terhadap kualitas audit. Sehingga auditor yang memiliki kompetensi yang tinggi dan independensi yang kuat maka akan menghasilkan kualitas audit yang baik.

\section{Keterbatasan}

Jumlah responden yang kurang pada KAP dan BPK Perwakilan RI di Sulawesi Utara dan pengukuran seluruh variabel mengandalkan pengukuran subyektif atau berdasarkan pada persepsi responden saja. Pengukuran subyektif rentan terhadap munculnya bias atau keasalahan pengukuran.

\section{Saran}

\section{A. Bagi Praktisi}

Audit sebaiknya dilakukan oleh auditor yang sudah berpengalaman dan dipandang mempunyai pengetahuan yang memadai serta mempunyai sikap mental independen yang tidak terpengaruh oleh klien atau siapapun yang dapat menurunkan kualitas audit dalam melaksanakan tugas auditnya. Disamping itu, harus dilakukan telaah hasil pemeriksaan auditor untuk menjamin bahwa pemeriksaan yang dilakukan telah sesuai dengan standar profesional yang berlaku dan berkualitas.

\section{B. Bagi Pengembangan Ilmu}

Keterbatasan-keterbatasan yang dikemukakan dalam penelitian ini dapat menjadi ajang perbaikan bagi peneliti sejenis di masa yang akan datang. Penelitian mendatang sebaiknya memperluas cakupan geografis sampel, misalnya dengan mengambil sampel auditor pada KAP dan BPK Perwakilan RI di kota-kota besar seluruh Indonesia, sehingga hasil penelitian memiliki daya generalisir yang lebih kuat. 


\section{DAFTAR PUSTAKA}

Alfred F. Kaunang , 2012, Pedoman Audit Internal, Jakarta : PT Bhuana Ilmu Populer

Alvin A. Arens, Randal J. Elder, Mark S. Beasley, 2010, terjemahan Gina Gania Auditing dan Jasa Assurance Pendekatan Terintegrasi, edisi 12, Jakarta : Erlangga

Amin Widjaja Tunggal, 2013, Auditng \& Assurance Services Kumpulan Soal dan Penyelesaian, Jakarta: Harvarindo

Anwar Nasution, 2007, Standar Pemeriksaan Keuangan Negara, Jakarta : Badan Pemeriksaan Keuangan Republik Indonesia

Asna Manulang, 2010, Pengaruh Tekanan Anggaran Waktu dan Resiko Kesalahan Terhadap Penurunan Kualitas Audit, STIE Pelita Nusantara Semarang, Semarang

Badan Pengawas Keuangan dan Pembangunan, 2010, Pendidikan, Pelatihan Dan Sertifikasi Auditor Aparat Pengawasan Intern Pemerintah PER - 1274/K/JF/2010, Jakarta : BPKP

Bambang Prasetyo dan Lina Miftahul Jannah, 2010, Metode Penelitian Kuantitatif Teori dan Aplikasi, Jakarta : PT. Rajagrafindo Persada

David P.E. Saerang, 2013, Buku Panduan Penulisan Skripsi dan Artikel, Manado: Fakultas Ekonomi dan Bisnis UNSRAT

Hery, S.E., M.Si., 2011, Auditing I Dasar-dasar Pemeriksaan Akuntansi, Edisi 1, Jakarta : Kencana Prenada Media Group

HM. Sonny Sumarsono, 2004, Metode Riset SDM, Yogyakarta : Graha Ilmu

Ikatan Akuntan Indonesia, 2001, Standar Profesional Akuntan Publik, Jakarta : Salemba Empat

John C. Maxwell, 2011, Etika Yang Perlu Diketahui Setiap Pemimpin, Jakarta : Libri

Maryanto Supriyanto, 2011, Buku Pintar Perbankan, Yogyakarta : Andi

Nugraha Eka Putra, 2012, "Pengaruh Kompetensi, Tekanan Waktu, Pengalaman Kerja, Etika, dan Independensi Auditor terhadap Kualitas Audit, Universitas Negeri Yogyakarta, Yogyakarta

Rahmadi Murwanto, Adi Budiarso, Fajar Hasri Ramadhana, Audit Sektor Publik Suatu Pengantar Bagi Pembangunan Akuntabilitas Instansi Pemerintah, LPKPAP BPPK Departemen Keuangan RI

Sekar Mayangsari dan Puspa Wandanarum, 2013, Auditing Pendekatan Sektor Publik dan Privat, Jakarta : Media Bangsa 